REVIEW PAPER

\title{
Recent Advances in Preparation and Functional Properties of Smoothie as Food: A Review
}

\author{
Aanchal Srivastava, Rajeev Kumar*, Akansha Arora, Jyoti Joshi and \\ Sanchit Vishnoi \\ Department of Food Technology, Uttaranchal University, Dehradun, Uttarakhand, India \\ *Corresponding author: rajeev.kumar267@gmail.com
}

Paper No.: 233

Received: 12-07-2019

Revised: 16-10-2019

Accepted: 29-11-2019

\begin{abstract}
The aim of this study was to to know the scenario of habit of consumption of fruits and vegetables amongst consumers and implement the concept of smoothie as an easy, nutritive and innovative form of their consumption. Smoothie is a liquid refreshing drink usually taken as health- conscious supplement for a healthy living. Smoothie contains either whole or different parts of fruit and vegetable. Fiber and juice are not separated from each other thus, increasing nutritive as well as digestive properties of the smoothie. Fruits and vegetables have low energy value but high nutritive physiological value. They are mainly constituted of starch and dietary fibers. They contain appreciable amount of micro-nutrients such as iron, calcium, phosphorus, magnesium, sodium and chromium. Fruits and vegetables are also rich in phytochemicals. These phytochemicals helps in reducing the possibilities of cancer. To increase the uptake of phytochemicals, food industries offer an alternate source of utilization of fresh fruits and vegetables as smoothie. To create distinct flavour and ease in consumption corresponding fruit juices or concentrates can also be used. The natural pigments and antioxidants present in fruits and vegetables also helps in glowing and smooth skin, also increasing better functioning and immunity of the body.
\end{abstract}

Keywords: Fruits, Smoothie, Consumption, Functionality, Nutritive value, etc.

Smoothie is an excellent and convenient substitute which promotes the intake to fresh fruits and vegetables on daily basis (Rodriguez-Verastegui, et al. 2015). They are non-alcoholic liquid refreshment drink usually made out of fresh or frozen fruits or vegetables. They are mixed together without straining and often served with crushed ice. Some smoothies may also contain other ingredients such as yoghurt, milk, ice-cream, lemonade, tea or spices and condiments. Their consistency is slightly concentrated than slushie (Castillejo et al. 2015). Smoothies have been mostly encouraged as fitness freak beverage option for wellbeing and healthy lifestyle. Considering the storage period, non-thermally processed smoothies are stored for shorter duration only due to possibility of increased microbial growth. The longer storage time may also result in degradation of natural colour and total phenols (Cano-Lamadrid, et al. 2018).

\section{CATEGORIES OF SMOOTHIES}

Smoothies can be sub-divided into three main categories viz. fruit only, Fruit and dairy product

How to cite this article: Srivastava, A., Kumar, R., Arora, A., Joshi, J. and Vishnoi, S. (2019). Recent Advances in Preparation and Functiona Properties of Smoothie as Food: A Review. Int. J. Food Ferment. Technol. 9(2): 89-100.

Source of Support: None; Conflict of Interest: None 
and functional smoothie. Functional smoothies are considered as the very recently available product in the market, usually containing probiotics amongst itself. Various types of Smoothies are described in Table 1. The advancement of consumption of fruits and vegetables is getting pronounced more than ever. This is caused by the desire of consumers for less processed, healthy and nutritive foods (Banigo et al. 2015; Zlabur et al. 2017). Smoothies are considered to contain one portion of fruit. Many commercially available smoothies are rich in calories and added sugars. Syrup-based fruit concentrates are being utilized instead of natural fruits, thereby resulting in a product high in sugar and lower in macro-nutrients especially vitamin C. The concept of consuming smoothie is not well known amongst citizens; almost more than a half of population prefers fruit juices over smoothies.

\section{ADVANTAGES OF SMOOTHIES}

Foods grown from the ground are considered as one of the basic piece of human sustenance (Boeing et al. 2012). They contain huge measure of small scale supplements making them progressively significant regarding nourishing physiology. They are rich water-solvent nutrients provitamin A, phytosterols and assortment of minerals (Gebbers, 2007). Various investigations have been recorded which shows that foods grown from the ground help in counteraction of certain chronical sicknesses for example hypertension (Dauchet et al. 2007), coronary heart maladies (Dauchet et al. 2006; He et al. 2007), and the danger of stroke (Dauchet et al. 2005; He et al. 2006). Regardless of the way that admission of leafy foods diminishes the event of illnesses, the utilization of products of the soil stay beneath the suggested levels (Mytton

Table 1: Different types of smoothies

\begin{tabular}{|c|c|c|c|c|}
\hline S1. No. & Constituents & Formulation & Analysis & Reference \\
\hline 1 & Apple Smoothie & $\begin{array}{l}\text { Apple phenolic extract, } \mathrm{CMC} \text {, citric } \\
\text { acid }\end{array}$ & $\begin{array}{l}\text { Apple Fibre, } \mathrm{N}_{2} \text { Physisorption, FTIR, } \\
\text { Total Dietary Fibre, Total Extracted } \\
\text { Polyphenol Content, HPLC, Rheo- } \\
\text { logical measurement }\end{array}$ & Sun-Waterhouse et al. 2013 \\
\hline 2 & Carrots Smoothie & Carrot: Water $=1: 1$ & $\begin{array}{l}\mathrm{pH}, \mathrm{TSS}, \text { titrable acidity, Brown- } \\
\text { ing index, Phenylalanine Ammo- } \\
\text { nia-Lyase, Total antioxidant capacity, } \\
\text { TPC }\end{array}$ & $\begin{array}{l}\text { Formica-Oliveira et al. } \\
(2017)\end{array}$ \\
\hline 3 & Fruit Smoothie & $\begin{array}{l}\text { Entire apple-29.5\% } \\
\text { Squeezed apple concentrates-29.5\% } \\
\text { Strawberry-21\% } \\
\text { Banana-12\% } \\
\text { Orange- } 8 \%\end{array}$ & $\begin{array}{l}\text { Polyphenols, HPLC-DAD (diode } \\
\text { ray detector), Hunter Lab, Dynamic } \\
\text { Oscillatory measurement, Sensory }\end{array}$ & Keenan et al. (2011) \\
\hline 4 & Pomegranate Smoothie & $\begin{array}{l}\text { Pomegranate: Figs + Jujubes + Quinc- } \\
\text { es Puree (60:40 \& 40:60), Rhubarb } \\
\text { Juice (5\%) }\end{array}$ & $\begin{array}{l}\text { Hunter Lab, UPLC-PDA (Ultra-per- } \\
\text { formance Liq. Chromatography-Pho- } \\
\text { todiode Array), Polymeric Procyani- } \\
\text { dins, Antioxidant Capacity, Four-way } \\
\text { Anova }\end{array}$ & Cano-Lamadrid, et al. (2018) \\
\hline 5 & Red and Green Smoothie & $\begin{array}{l}26 \% \text { Cherries, } 8 \% \text { Tomatoes, } 5 \% \\
\text { Blackberries, } 31 \% \text { Prunes for Red } \\
\text { Smoothie } \\
40 \% \text { Kiwi, } 7 \% \text { Fennel, } 8 \% \text { Spinach, } \\
15 \% \text { Papaya for Green Smoothie } \\
\text { White grape juice- } 20 \% \\
\text { Aloe vera- } 10 \%\end{array}$ & $\begin{array}{l}\text { Microbiological, pH, soluble solids, } \\
\text { titrable acidity, apparent viscosity, } \\
\text { colour, browning index, soluble di- } \\
\text { etary fibres, total polyphenolic com- } \\
\text { pounds, Organic acids and sugars, } \\
\text { ascorbic acid, antioxidant activity }\end{array}$ & Cagno, et al. (2011) \\
\hline
\end{tabular}


Recent Advances in Preparation and Functional Properties of Smoothie as Food: A Review

\begin{tabular}{|c|c|c|c|c|}
\hline 6 & Purple Smoothie & $\begin{array}{l}\text { Beetroot- } 12 \% \\
\text { Purple grapes- } 45 \% \\
\text { Cucumber- } 35 \% \\
\text { Broccoli- } 8 \%\end{array}$ & $\begin{array}{l}\text { Sensory, Microbial, Vitamin C, TPC, } \\
\text { Total antioxidant content (TAC), } \\
\text { Anthocyanin }\end{array}$ & $\begin{array}{l}\text { Gonzalez-Tejedor et al. } \\
(2017)\end{array}$ \\
\hline 7 & Fruit Smoothie & $\begin{array}{l}\text { Apple Juice- } 33 \% \\
\text { Orange Juice- } 33 \% \\
\text { Strawberry- } 14 \% \\
\text { Whole Apple- } 10 \% \\
\text { Banana- } 10 \%\end{array}$ & $\begin{array}{l}\text { Sensory, Peroxidase enzyme activity, } \\
\text { Polyphenol oxidase enzyme activity, } \\
\text { Pectin methyl esterase enzyme activ- } \\
\text { ity, Antioxidant, Density, Viscosity, } \\
\text { Total soluble and insoluble solids, } \\
\text { Turbidity and Transmittance, Hunter } \\
\text { Lab, Browning Index, Total Acidity, } \\
\text { pH, Vitamin C, Total Phenols and } \\
\text { Flavonoids, Sugars, Microbial }\end{array}$ & Hurtado et al. (2015) \\
\hline 8 & Kiwi Smoothie & $\begin{array}{l}\text { Kiwi- } 3 \mathrm{~kg} \\
\text { Sugar- } 0 \%, 10 \%, 15 \%, 20 \%, 25 \%\end{array}$ & $\begin{array}{l}\text { Bioactive compounds, TAC, Total } \\
\text { Chlorophyll, Total Carotenoid, Total } \\
\text { Ascorbic Acid, Fluorometric mea- } \\
\text { surement, FTIR }\end{array}$ & Park et al. (2016) \\
\hline 9 & $\begin{array}{l}\text { Mixed Fruit with Coconut } \\
\text { Milk Smoothie }\end{array}$ & $\begin{array}{l}\text { Pineapple- } 50 \mathrm{~g} \\
\text { Banana- } 28 \mathrm{~g} \\
\text { Apples- } 12 \mathrm{~g} \\
\text { Orange- } 3 \mathrm{~g} \\
\text { Coconut milk- } 7 \mathrm{~g} \\
\text { (per 100g smoothie) }\end{array}$ & $\begin{array}{l}\text { Microbiological, Shelf-life analysis, } \\
\text { Sensory analysis, Heat and Pulsed } \\
\text { electric field and thermal pasteuriza- } \\
\text { tion for preservation }\end{array}$ & $\begin{array}{l}\text { Walkling-Ribeiro, et al. } \\
(2010)\end{array}$ \\
\hline 10 & $\begin{array}{l}\text { Aloe gel- spiced ripened } \\
\text { papaya Smoothie }\end{array}$ & $\begin{array}{l}\text { Papaya pulp- } 15 \% \\
\text { Sugar Syrup- } 20 \% \\
\text { Aniseed, Ginger and Pepper- } 5 \% \\
\text { Citric Acid- } 0.1 \% \\
\text { Aloe gel- } 10 \%, 20 \%, 30 \%\end{array}$ & $\begin{array}{l}\text { pH, Titrable acidity, TSS, non-enzy- } \\
\text { matic browning, Total and reducing } \\
\text { sugar, Hunter Colour Lab, Vitamin } \\
\text { C, Total flavonoids, Total polyphe- } \\
\text { nols, Microbial analysis, Sensory } \\
\text { acceptability }\end{array}$ & $\begin{array}{l}\text { Ramachandran \& Nagara- } \\
\text { jan (2014) }\end{array}$ \\
\hline 11 & Dehydrated Smoothie & $\begin{array}{l}\text { Dehydrated Banana, Dehydrated } \\
\text { Strawberries, Dehydrated egg white, } \\
\text { Demerara sugar }(2 \%) \\
\text { Cold water/cold whole milk }\end{array}$ & Sensory, Viscosity, Hunter Lab & Guazi et al. (2019) \\
\hline
\end{tabular}

et al. 2014). Accordingly, to take out this propensity and present a sound living, exchanges, for example, juices, mixes, smoothies and matured and sustained refreshments are a well-known path for foods grown from the ground utilization (Wootton-Beard and Ryan, 2011; Corbo et al. 2014; Marsh et al. 2014; Ramachandran and Nagarajan, 2014 and Hurtado et al. 2015).

Due to health-promoting properties, diets rich in fruits and vegetables are highly recommended. They possess a superior place due to their concentrations of vitamins, especially water soluble; minerals, especially electrolytes; and more commonly phytochemicals such as antioxidants (Slavin and Lloyd, 2012). Avocado, potatoes, dried beans and corn are wealthy in start while yams are nearly sucrose and not starch. Natural products, aside from banana, and dull green vegetables contain next to zero starch. It is important to understand the categories of fruits and vegetables to ensure proper dietary intake in accordance with dietary recommendations. Fruits 
and vegetables are usually low in energy density and excellent wellsprings of fiber and potassium (Hornick and Weiss, 2011).

Natural products generally contain sugars and fibers, for example, gelatin, that are widely matured in the internal organ. Natural products, for example, apples and pears, are packed in fructose (Southgate et al. 1978). Apples display $6 \%$ fructose and $3 \%$ sucrose though pears contain about $6.5 \%$ fructose and $1.3 \%$ sucrose; these qualities would be predictable in their particular juices. Admission of foods grown from the ground decreases the event of oxidative pressure related infections (Escudero-Lopez et al. 2016). Smoothies are a great and appropriate choice to advance the everyday usage of products of the soil (Rodriguez-Verastegui et al. 2015). Epidemiological examinations show that there is an away from between admission of products of the soil and diminished pace of heart infections mortality, normal malignant growths and other degenerative illnesses including maturing (Steinmetz and Potter, 1996; Garcia-Closas et al. 1999; Joseph et al. 1999; Dillard and German, 2000; Prior and Cao, 2000; Wargovich, 2000). It mainly helps in reducing the risk of cancers of the mouth and pharynx, oesophagus, lung, stomach and colon.

Blending is an alternate to reduce under-utilization of vegetables, fruits, spices and condiments. It may be attributed to alter dietary intake, taste preference and way of life of consumers. The demand of blended smoothies has been increasing with each passing year due to their health benefits and amazing taste. Therefore, to enhance taste, flavor, palatability, aroma and nutritive properties of any particular fruit or vegetable, it is aimed to be convenient to blend it with highly nutritive fruits and vegetables of other variety.

\section{BEVERAGES}

Water balance inside human body can be maintained by consuming an adequate amount of water which is equal to amount of water being excreted out. Human body keeps water balance in harmony state by controlling admission and discharge (Sayed and Abdellatif, 2018). Refreshments add to prerequisites of water in human. Troiano et al. 2000 detailed that around $20-24 \%$ of vitality consumption originates from drinks. Notwithstanding satisfying essential prerequisite, drinks turned into a piece of culture of human culture. Assortment of drinks taken influences arrangement of present day diet (Stubbs and Whybrow, 2004). These drinks are in top ten contributing nourishments for a few supplements. Natural product juices adds to vitality, calcium, iron, vitamin $\mathrm{C}$, vitamin $\mathrm{A}$ and fiber consumption while milk adds to vitality, protein, fat, calcium, and nutrient An admission (Zohouri, et al. 2004).

\section{SMOOTHIE}

The concept of smoothies came into vision in 1990s and is one of the major growing sectors of beverage industry (Mordor Intelligence, 2017). Smoothies are progressively famous method of expending organic product. It should contain minimum of one portion of fruit. To increase the consumption and eating interest of consumers, it is the best way to process fruits and vegetables through different methods (Bates and Price, 2015). Smoothies are generally made up by joining entire foods grown from the ground which keeps up fiber despite the fact that squeezing will in general abandon a mash containing fiber however in any case holds its dietary benefit (Clemens et al. 2015).

As of late, smoothies have increased a lot of notoriety for example development of item ascends from 2.39 occasions from 2002 to 2007 according to food merchandiser (Lal, 2007). Smoothies are a superb and helpful source to improve the day by day utilization of products of the soil (Rodriguez-Verastegui et al. 2015). Comfort and fitness food properties are two most significant variables for high-pace way of life. Changes in dietary admission are most earlier treatment for development of human wellbeing (Williams et al. 2004; Sabbe et al. 2009; Verbeke et al. 2009; Faresjo et al. 2010; Krystallis et al. 2010). 


\section{PREPARATION AND PRESERVATION OF SMOOTHIES}

The time span of usability of unpasteurized smoothies is relatively shorter because of microbial development accordingly negligible degree of preparation are related with these items. These are ordinarily expended either new or protected for brief timeframe (1-3 weeks) by putting away them under refrigeration conditions. A few specialists proposed that it could be worth to utilize a gentle warm sanitization treatment (Walkling-Ribeiro, et al. 2010) or a warm and high hydrostatic weight handling to degree their time span of usability and for predominant shading maintenance, polyphenols and other quality characteristics, ensuring purchasers acknowledgment and sanitation (Keenan, et al. 2011; Tiwari, 2018).

Low thermal processing is projected which enables retaining colour, consistency, fresh flavour, and ascorbic acid content. Acidification may convert low acid juice to an acidic juice allowing milder thermal process conditions (Agarwal \& Kumar, 2017).

\section{FUNCTIONAL PROPERTIES OF SMOOTHIE}

The rule job of products of the soil was by and large generally explored from most recent a very long while because of its high fiber substance and wealth of nutrients and minerals. It has been acknowledged because of its recipient impact on human wellbeing, introducing general wellbeing endeavors, for example, ' 5 per Day for Better Health', $\mathrm{DASH}$ diet and incorporation in the American Heart Association (AHA) dietary rules to upgrade utilization to improve human wellbeing (Tucker, 2004). Expanded admission of products of the soil helps in counteraction of constant and degenerative illnesses. In this way products of the soil are accepting a nickname as "useful nourishments" (Whitney and Rolfes, 2008).

Useful non-mixed drink industry is a quickest developing division and it is ceaselessly getting new items and bundling styles advertise. Increment in purchaser's interest for helpful beverages and its suggestion on solid way of life is the impetus of industry's development. Being non-improved included characteristic flavors and enhanced with nutrients and minerals is a sound option in contrast to sodas (Suhag and Singh, 2017). Certain practical drinks have been created to give explicit health advantages. Numerous epidemiologic and clinical researches depicts multi advantages of products of the soil in human day by day diet for avoidance from intense and interminable afflictions (Lock et al. 2004).

Smoothies are generally made up from products of the soil which are wealthy in phenolic mixes. These phenolic mixes are acceptable wellspring of cell reinforcements liable for wellbeing advancing properties, for example, calming, antitumoral, forestalling neurodegenerative and interminable infections (El Gharras, 2009). Essential (shikimate) and auxiliary (phenylpropanoid) pathways are most regular pathways that occurred for the biosynthesis of polyphenolic mixes which happens within the sight of key chemical phenylalanine smelling salts lyase (PAL) (Dixon and Paiva, 1995). It was proposed that PAL movement can be expanded by a variety of biotic and abiotic stress-actuated components, for example, injuring, radiation presentation, hyperoxia capacity, chilling injury, water pressure, low minerals, hormones, ultrasounds, and pathogen assault (Cisneros-Zevallos, 2003; Cuellar-Villarreal et al. 2016).

Apple is considered as a best source of a healthy diet. They contain high amount of polyphenolic compounds and dietary fibers. It helps in preventing digestive problems, chronic disorders, respiratory cancer, asthma, diabetes type 2, thrombotic stroke and ischaemic heart problems (Lee et al. 2003; Boyer and Liu, 2004; Schulze et al. 2004; McGhie et al. 2005; Okoko et al. 2007; Hansen et al. 2009; Sun-Waterhouse et al. 2008a, b, 2011; Chai et al. 2011). Fresh apple prevents constipation, reduces dental caries, controls obesity and provide extra energy for heavy exercise. The apple fruit pulp is found to be richest source of phytochemicals like catechin, quercetin, phloridzin and chlorogenic acids. They are strong antioxidants which decrease the risk of cancers, cardiovascular 
diseases, asthma and diabetes. These phytochemicals inhibits cancer cell proliferation, reduces lipid oxidation and lower cholesterol (Boyer \& Liu, 2004).

Green leafy vegetables are separated and investigated independently from fruits and vegetables. There are few studies according to which green leafy vegetables possess protective effects and studies have shown that including them in regular diets is beneficial as due to their superiority in nutritive quantity amongst fruits and vegetables (Hung et al. 2004; Johnston et al. 2000; Zhang et al. 2011).

Milk is considered as a rich source of calcium, which is an essential nutrient for growth and development of strong bones and teeth, muscle movement and nerve signals. Many related organizations exclaim that getting enough amount of calcium in daily diet results in preventing bone fracture and osteoporosis. It is also a good source of potassium which helps blood vessels dilate and reduce blood pressure. Increased level of potassium rather than sodium intake helps in reducing blood pressure, lowering risk of heart disease and stroke (Miller et al. 1995; McCarron, 1998). The components such as calcium, vitamin D, lactic acid bacteria, linoleic acid and bioactive peptides present in dairy products could protect against colon cancer (Mobarhan, 2009; Garland et al. 1991; Ouwehand et al. 1999; McIntosh, et al. 1998).

Smoothies are made up by combining together fruit, fruit juice, ice, and yoghurt or milk. Between 2002 and 2006, the market share increased to $214 \%$ in Republic of Ireland (Mintel Group, 2008). Oey et al. (2008) have investigated various possible substitutes to warm preparing of natural product beverages to limit the conceivable negative effect that warm handling may have, coming about in negligibly prepared new items without concession towards timeframe of realistic usability. The execution of high hydrostatic weight (HHP) (up to $700 \mathrm{Mpa}$ ) can impact in protein inactivation and a gentle sanitization to food items at encompassing temperatures (Meyer et al. 2000; Weemaes et al. 1999).

Patras et al. (2009) suggests that, HHP can be used to retain nutritional attributes of antioxidant rich fruits due to its property of affecting high atomic weight sub-atomic structure, for example, sugars and proteins in food. It doesn't influence littler particles connected along with organoleptic, dietary and wellbeing advancing properties. Smoothies are considered as a mainstream method of devouring organic product homogenates containing mash. They contribute towards a healthier diet and lifestyle. It comprises of numerous ingredients from fruit to dairy products, from pulp to yoghurt and sometimes sweeteners (Walkling-Ribeiro et al. 2010).

According to Hurtado et al. (2015) studies published up till now on high pressure processing (HPP) was carried out on individual fruit products. In recent years, some studies and researches have also been developed on blended fruit mixtures. Different pressurizing conditions were trialed to obtain products with organoleptic and nutritional characteristics normally in relation with "minimally processed" fruit.

Balaswamy et al. (2013) in their study regarding advancement of smoothies from chosen organic products pulps/juices aimed to blend different fruit pulp i.e. mango, banana, sapota, papaya and juices viz. grapes, phalsa, pineapple, watermelon and pomegranate of optimal quantities. The fruits were mixed in a manner that it provide required consistency as well as was compliant to thermal preservation processes in glass bottles. The blending also helped in manageable sugar acid ratio together with better colour and flavour without using preservative. Combining and mixing various fruit pulps and juices helps utmost use of natural product pulps and squeezes and furthermore help to sustain wholesome status of the populace.

\section{MARKET SCENARIO}

It is important for the consumers to increase their awareness level followed with new trends and innovations. Awareness regarding ingredients associated with product and nutritional and adverse effects of the final product. It is an important criteria as some ingredients can be consumed by every age 
group while some may cause fatal symptoms on wellness of the person (Olivo, 2015). Consumption of fruits and vegetables either in their original form or other variety is directly in relation to prevention and treatment of any acute or chronic diseases. As functional foods provide more than just nutrition thus it is gaining popularity around the consumers. According to Levy \& Tapsell, (2007), due to emerging trends and consumers' specific needs, new variety of products could be witnessed in the market with natural and functional ingredients.

All around, admission of foods grown from the ground by larger part of individuals is underneath the day by day suggested dietary necessities. Researchers exclaimed that in developed countries such as Australia, Europe, Canada, UK and USA a large gap is observed between actual intake of fruits and vegetables to recommended servings. From an investigation inside 52 low and center salary nations about $77.6 \%$ men and $78.4 \%$ ladies are expending not as much as that of suggested dietary cutoff points. According to the same study, $74 \%$ low consumption is reported amongst adult of India (Hall et al. 2009).

India being the second largest producer of fruits and vegetables in the world grows almost all varieties of fruits and vegetables which contribute about $92.3 \%$ of total horticultural production within the country. Yearly utilization ( $\mathrm{kg} /$ individual/annum) of organic products was 9.6 for provincial, 15.6 for urban and generally speaking India is 11.8 though if there should arise an occurrence of vegetables 74.3 (rustic), 79.1 (urban) and 76.1 (India) (NSSO). From the aggregate of green creation, just $2 \%$ of these yields are prepared into esteem included items, for example, sticks and jams, squeezes and thinks, canned and dried out items, mash, pickles and chutneys. In the contrary, processing of these value-added products ranges between $80 \%$ to $30 \%$ in countries like USA, China, South Africa, Brazil, Chile, Philippines, Malaysia, Thailand, etc. (Kaul, 1998; Goyal, 2006).

McCartney et al. (2018) designed an online survey among Australian adults constituting about 79\% female to recognize the smoothie consumption pattern and individual motives behind its intake. Candidates reported consuming 98\% fruit, $46 \%$ fruit juice, $66 \%$ yoghurt, $52 \%$ honey and $58 \%$ milk and $46 \%$ nutritional supplements in their smoothies. Visit smoothie purchasers were found to devour more center food and rather less intentional things, for example, nectar, frozen yogurt, and so on in contrast with rare smoothie buyers. These frequent smoothie consumers perceives smoothie as nutritious (84\%) while infrequent smoothie consumers regarded smoothie as indulgent beverages (62\%).

\section{RECENT TRENDS AND INNOVATIONS}

Varous recent trends and Innovations made in Smoothies preparation are summarized in Table 2.

\section{Limitations}

The study regarding smoothie and its consumption is limited because of a little awareness about physiological and nutritional value of ingredients and amount present in final product among

Table 2: Recent Trends and Innovation

\begin{tabular}{|c|c|c|c|c|}
\hline S1. No. & Constituents & Formulations & Observations & Reference \\
\hline 1 & Cereal-milk fruit smoothie & $\begin{array}{l}\text { Full Cream Milk- 42.4\% } \\
\text { Banana-26.2\% } \\
\text { Blueberry- } 14.5 \% \\
\text { Yoghurt-11.3\% } \\
\text { SMP- 3.0\% } \\
\text { Psyllium husk- 2.5\% } \\
\text { Water }\end{array}$ & $\begin{array}{l}\text { Comparative survey on difference in } \\
\text { dietary behaviour }\end{array}$ & McCartney et al. (2019) \\
\hline
\end{tabular}


Srivastava et al.

\begin{tabular}{|c|c|c|c|c|}
\hline 2 & Detox Smoothie & $\begin{array}{l}\text { Mixed e.g. Green and red juice } \\
\text { smoothies, Wellness shots, Nuts } \\
\text { shakes and filling smoothie }\end{array}$ & $\begin{array}{l}\text { Recipe Book consisting of different } \\
\text { types of healthy smoothies }\end{array}$ & Maranik, E. (2015) \\
\hline 3 & Flour-Milk based smoothie & $\begin{array}{l}\text { Dairy animals milk: } 3 \% \text { Fat, } 8.5 \% \\
\text { SNF } \\
\text { Sprouted finger millet flour, Ger- } \\
\text { minated sorghum flour, Germinat- } \\
\text { ed green gram flour, Germinated } \\
\text { chickpea flour, flour went between } \\
2-6 \% \\
\text { Mango mash } 10 \% 15 \% \text { and } 20 \% \text {, } \\
\text { Sugar- } 9 \% 10 \% \text { and } 11 \%\end{array}$ & \begin{tabular}{|l|} 
Sensory evaluation, \\
Effect of apple juice and mango pulp \\
on sensory attributes, \\
Effect of flour levels on sensory \\
attributes, \\
Effect of sugar level on sensory \\
attributes
\end{tabular} & Rani et al. (2016) \\
\hline 4 & Green coconut smoothie & $\begin{array}{l}\text { Solid albumen of green coconut- } \\
20 \% \\
\text { Acerola pulp, pineapple pulp and } \\
\text { coconut water- different ratios }\end{array}$ & $\begin{array}{l}\text { Vitamin C content, } \\
\text { Antioxidant capacity, } \\
\text { Sensory acceptability, } \\
\text { Total Phenolic Compounds, } \\
\text { pH, Titrable acidity, TSS }\end{array}$ & Teixeira et al. (2019) \\
\hline 5 & Chikoo Chia Smoothie & $\begin{array}{l}\text { Chikoo }-50 \mathrm{~g} \\
\text { Curd- } 25 \mathrm{~g} \\
\text { Honey- } 10 \mathrm{~g} \\
\text { Milk- } 125 \mathrm{ml} \\
\text { Chia seeds in ratios } 4 \mathrm{~g}, 8 \mathrm{~g} \text { and } 12 \mathrm{~g}\end{array}$ & $\begin{array}{l}\text { Colour, Consistency, Taste, Overall } \\
\text { acceptability }\end{array}$ & Battalwar \& Shah (2015) \\
\hline 6 & $\begin{array}{l}\text { Pumpkin leaves fortified } \\
\text { Smoothie }\end{array}$ & $\begin{array}{l}\text { Pineapple, Banana, Apple, Pump- } \\
\text { kin leaves }(4.5 \%, 3 \% \text { and } 1.5 \%)\end{array}$ & $\begin{array}{l}\text { Proximate analysis, Vitamin C, Min- } \\
\text { eral content, Total flavonoids, Total } \\
\text { Phenolic, Antioxidants, Sensory }\end{array}$ & Aderinola (2018) \\
\hline 7 & Jamun Synbiotic Smoothie & $\begin{array}{l}\text { Skim milk, SMP, Yoghurt, Sugar, } \\
\text { Jamun juice }\end{array}$ & $\begin{array}{l}\text { Proximate analysis, Shelf life at } \\
\text { refrigerated temperature, Sensory } \\
\text { evaluation, Prebiotic effect for micro- } \\
\text { encapsulation, pH, acidity, viscosity, } \\
\text { total viable count, antioxidant, total } \\
\text { phenolic compounds, ascorbic acid. }\end{array}$ & Saranyambiga, et al. (2017) \\
\hline 8 & $\begin{array}{l}\text { Soy/Carrot Flavoured with } \\
\text { Beetroot }\end{array}$ & $\begin{array}{l}\text { Soybean milk: water }=1: 10 \\
\text { Beetroot/Carrot pulp: water= 1:4 }\end{array}$ & $\begin{array}{l}\text { Viscosity, pH, TSS, Sensory Evalua- } \\
\text { tion, Proximate Analysis }\end{array}$ & Banigo, et al. (2015) \\
\hline 9 & $\begin{array}{l}\text { Olive Leaf Extract fortified } \\
\text { smoothie }\end{array}$ & $\begin{array}{l}\text { Sodium cyclamate, sucrose, sodi- } \\
\text { um chloride, citric acid, Strawber- } \\
\text { ry-Banana smoothie, Olive leaf } \\
\text { extract with oleuropein content, } \\
\text { modified starch }\end{array}$ & Threshold Test, Ranking Test & Kranz, et al. (2010) \\
\hline
\end{tabular}

consumers. The smoothie is not well differentiated from the term soft drinks and health beverages. Numerous researches are available on consumption of whole fruit in its actual form or alternatives like juices, concentrates, etc. but no specific clinical health research is exhibited regarding consumption of smoothies. Smoothies being available in market are high in sugar content and thus making it unhealthy in perspective of energy and low calorific food product.

\section{CONCLUSION}

The review paper highlights the preparation of various smoothies depending on availability of seasonal fruits and the taste of consumers. Various 
types of smoothies, market scenario, limitations and functional properties of smoothie are well covered in this review paper. Numerous researches are available on consumption of whole fruit in its actual form or alternatives like juices, concentrates, etc. but no specific clinical health research is exhibited regarding consumption of smoothies. Furthermore, many of the constraints in smoothies can be minimized through its commercialization and research that makes in utilizing various perishable seasonal fruits into value added nutritive products, which in turn enhances its economic demand.

\section{REFERENCES}

Aderinola, T.A. 2018. Effects of pumpkin leaves on the chemical composition and antioxidant properties of smoothies. Regional food science and technology summits, Akure, 281-287.

Agarwal, S. and Kumar, V. 2017. Effect of Physico-chemical changes of RTS beverage bottle gourd juice blends with mint and lemon. International Journal of Chemical Studies, 5(4): 355-358.

Balaswamy, K., Prabhakara Rao, P.G., Nagender, A., Narsing Rao, G., Sathiya Mala, K., Jyothirmayi, T., Math, R.G. and Satyanarayana, A. 2013. Development of smoothies from selected fruit pulps/juices. International Food Research Journal, 20(3): 1181-1185.

Banigo, E.B., Kiin-Kabari, D.B. and Owuno, F. 2015. Physicochemical and sensory evaluation of soy/carrot drinks flavoured with beetroot. African Journal of Food Science and Technology, 6(5): 136-140.

Bates, D. and Price, J. 2015. Impact of fruit smoothies on adolescent fruit consumption at school. Health Education and Behaviour, pp. 1-6.

Battalwar, R. and Shah, V. 2015. Incorporation of chia seeds in fruit punch, kheer, smoothie and its sensory evaluation. International Journal of Food and Nutritional Sciences, 4(1): 8490.

Boeing, H., Bechthold, A., Bub, A., Ellinger, S., Haller, D., Kroke, A., Leschik-Bonnet, E., Muller, M.J., Oberritter, H., Schulze, M., Stehle, P. and Watzl, B. 2012. Critical review: vegetables and fruit in the prevention of chronic diseases. European Journal of Nutrition, 51: 637-663.

Boyer, J. and Liu, R.H. 2004. Apple phytochemicals and their health benefits. Nutrition Journal, 3(5): 1-15.

Cagno, R.D., Minervini, G., Rizzello, C.G., Angelis, M.D. and Gobbetti, M. 2011. Effect of lactic acid fermentation on antioxidant, texture, colour and sensory properties of red and green smoothie. Food Microbiology, 28: 1062-1071.

Cano-Lamadrid, M., Hernandez, F., Nowicka, P., Carbonell-
Barrachina, A.A. and Wojdylo, A. 2018. Formulation and storage effects on pomegranate smoothie phenolic composition, antioxidant capacity and colour. LWT- Food Science and Technology, 96: 322-328.

Castillejo, N., Martínez-Hernández, G.B., Gómez, P.A., Artés, F. and Artés-Hernández, F. 2015. Red fresh vegetables smoothies with extended shelf-life as an innovative source of health-promoting compounds. Journal of Food Science and Technology, pp. 1-12.

Chai, S.C., Hooshmand, S., Saadat, R.L. and Arjmandi, B.H. 2011. Daily apple consumption promotes cardiovascular health in postmenopausal women. Journal of the Federation of American Societies for Experimental Biology, 25: 971.10.

Cisneros-Zevallos, L. 2003. The use of controlled postharvest abiotic stresses as a tool for enhancing the nutraceutical content and adding value of fresh fruits and vegetables. Journal of Food Science, 68(5): 1560-1565.

Clemens, R., Drewnowski, A., Ferruzzi, M.G., Toner, C.D. and Welland, D. 2015. Squeezing fact from fiction about $100 \%$ fruit juice. Adv. Nutr., 6: 236S-243S.

Corbo, M.R., Bevilacqua, A., Petruzzi, L., Casanova, F.P. and Sinigaglia, M. 2014. Functional beverages: the emerging side of functional foods: commercial trends, research, and health implications. Compr. Rev. Food Sci. F., 13(1): 192-206.

Cuellar-Villarreal, M.D.R., Ortega-Hernandez, E., BecerraMoreno, A., Welti-Chanes, J., Cisneros-Zevallos, L. and Jacobo-Velazquez, D.A. 2016. Effects of ultrasound treatment and storage time on the extractability and biosynthesis of nutraceuticals in carrot (Daucus carota). Post-harvest Biology and Technology, 119: 18 -26.

Dauchet, L., Amouyel, P. and Dallongeville, J. 2005. Fruit and vegetable consumption and risk of stroke: a meta-analysis of cohort studies. Neurology, 65(8): 1193-1197.

Dauchet, L., Amouyel, P., Hercberg, S. and Dallongeville, J. 2006. Fruit and vegetable consumption and risk of coronary heart disease: a meta-analysis of cohort studies. Journal of Nutrition, 136(10): 2588-2593.

Dauchet, L., Kesse-Guyot, E., Czernichow, S., Bertrais, S., Estaquio, C., Peneau, S., Vergnaud, A.-C., Chat-Yung, S., Castetbon, K., Deschamps, V., Brindel, P. and Hercberg, S. 2007. Dietary patterns and blood pressure change over 5-y follow-up in the SU.VI.MAX cohort. The American Journal of Clinical Nutrition, 85(6): 1650-1656.

Dixon, R.A. and Paiva, N.L. 1995. Stress-induced phenylpropanoid metabolism. The Plant Cell, 7(7): 10851097.

El Gharras, H. 2009. Polyphenols: food sources, properties and applications - a review. International Journal of Food Science $\mathcal{E}$ Technology, 44(12): 2512-2518.

Escudero-Lopez, B., Cerrillo, I., Gil-Izquierdo, A., HorneroMendez, D., Herrero-Martın, G., Berna, G., Medina, S., 
Ferreres, F., Martın, F. and Fernandez-Pachon, M.S. 2016. Effect of thermal processing on the profile of bioactive compounds and antioxidant capacity of fermented orange juice. Int. J. Food Sci. Nutr., 67: 779-788.

Faresjo, A., Johansson, S., Faresjo, T., Roos, S. and Hallert, C. 2010. Sex differences in dietary coping with gastrointestinal symptoms. European Journal of Gastroenterology and Hepatology, 22(3): 327-333.

Formica-Oliveira, A.C., Martinez-Hernandez, G.B., Aguayo, E., Gomez, P.A., Artes, F. and Artes-Hernandez, F. 2017. A functional smoothie from carrots with induced enhanced phenolic contents. Food Bioprocess Technology, 10: 491-502.

Garcia-Closas, R., Gonzalez, C.A., Agudo, A. and Riboli, E. 1999. Intake of specific carotenoids and Flavonoids and the risk of gastric cancer in Spain. Cancer Causes and Control, 10: 71-75.

Garland, C.F., Garland, F.C. and Gorham, E.D. 1991. Can colon cancer incidence and death rates be reduced with calcium and vitamin D? The American Journal of clinical nutrition, 54(1): 193S-201S.

Gebbers, J.-O. 2007. Atherosclerosis, cholesterol, nutrition and statins- a critical review. German Medical Science, 5: 1-11.

Gonzalez-Tejedor, G.A., Martinez-Harnandez, G.B., Garre, A., Egea, J.A., Fernandez, P.S. and Artes-Hernandez, S. 2017. Quality changes and shelf-life prediction of a fresh fruit and vegetable purple smoothie. Food and Bioprocess Technology, 10(10): 1892-1904.

Goyal, S.K. 2006. Potentianl in agribusiness-fruit and vegetable processing industry in India. J. International Farm Management, 3: 2-15.

Guazi, J.S., Lago-Vanzela, E.S. and Conti-Silva, A.C. 2019. Development of smoothies from dehydrated products of strawberry and banana pulp obtained from foam-mat drying. International Journal of Food Science and Technology, 54: 54-61.

Hall, J.N., Moore, S., Harper, S.B. and Lynch, J.W. 2009. Global variability in fruit and vegetable consumption. Am. J. Prev. Med., 36: 402-409.

Hansen, L., Vehof, H., Dragsted, L.O., Olsen, A., Christensen, J., Overvad, K. and Tjonneland, A. 2009. Fruit and vegetable intake and serum cholesterol levels: a cross-sectional study in the diet, cancer and health cohort. Journal of Horticultural Science \& Biotechnology, ISAFRUIT Special Issue, pp. 42 -46.

He, F.J., Nowson, C. A. and MacGregor, G.A. 2006. Fruit and vegetable consumption and stroke: meta-analysis of cohort studies. Lancet, 367(9507): 320-326.

He, F.J., Nowson, C. A., Lucas, M. and MacGregor, G.A. 2007. Increased consumption of fruits and vegetables is related to a reduced risk of coronary heart disease: meta-analysis of cohort studies. Journal of Human Hypertension, 21(9): 717728 .
Hornick, B.A. and Weiss, L. 2011. Comparative nutrient analysis of commonly consumed vegetables. Nutrition Today, 46: 130-137.

Household consumption of various goods and services in India: $66^{\text {th }}$ Round 2009-10. National Sample Survey Office (NSSO), Ministry of Statistics and Programme Implementation, New Delhi: Government of India; 2012.

Hung, H., Joshipura, K.J., Jiang, R., Hu, F.B., Hunter, D., Smith-Warner, S.A., Colditz, G. A., Rosner, B., Spiegelman, D. and Wilett, W.C. 2004. Fruit and vegetable intake and risk of major chronic disease. Journal of the National Cancer Institute, 96(21): 1577-1584.

Hurtado, A., Picouet, P., Jofre, A., Guardia, M.D., Ros, J.M. and Banon, S. 2015. Application of high pressure processing for obtaining "fresh-like" fruit smoothies. Food Bioprocess Technol, 8(2): 2470-2482.

Johnston, C.S., Taylor, C.A. and Hampl, J.S. 2000. More Americans are eating "5 a day" but intakes of dark leafy green and cruciferous vegetables remain low. American Society for Nutritional Sciences, 130(12): 3063-3067.

Joseph, J.A., Shukit-Hale, B., Denisova, N.A., Bielinski, D., Martin, A., McEwen, J.J. and Bickford, P.C. 1999. Reversal of age-related declines in neuronal signal transduction, cognitive, and motor behavioural deficits with blue berry, spinach, or strawberry dietary supplementation. Journal of Neuroscience, 19: 8114-8812.

Kaul, G.L. 1998. Fruit and vegetable production in India. Nutrition Foundation of India Bulletin, 19: 5-8.

Keenan, D. F., Brunton, N., Gormley, R. and Butler, F. 2011. Effects of thermal and high hydrostatic pressure processing and storage on the content of polyphenols and some quality attributes of fruit smoothies. Journal of Agricultural and Food Chemistry, 59(2): 601-607.

Kranz, P., Braun, N., Schulze, N. and Kunz, B. 2010. Sensory quality of functional beverages: Bitterness perception and bitter masking of olive leaf extract fortified fruit smoothies. Journal of Food Science, 75(6): 308-311.

Krystallis, A., Linardakis, M. and Mamalis, S. 2010. Usefulness of the discrete choice methodology for marketing decisionmaking in new product development: an example from the European functional foods market. Agribusiness, 26(1): $100-121$.

Lal, G.G. 2007. Getting specific with functional beverages. Food Technology, 61(12): 24-31.

Lee, K., Kim, Y., Kim, D., Lee, H. and Lee, C. 2003. Major phenolics in apple and their contribution to the total antioxidant capacity. Journal of Agricultural and Food Chemistry, 51: 6516-6520.

Levy, G. and Tapsell, L. 2007. Shifts in purchasing patterns of non-alcoholic, water based beverages in Australia, 1997-2006. Nutrition $\mathcal{E}$ dietetics the journal of the Dietitians Association of Australia, 64: 4. 
Lock, K., Pomerleau, J., Causer, L. and McKee, M. 2004. Low fruit and vegetable consumption. In Ezzati, M., Lopez, A.D., Rodgers, A. and Murray, C.J.L. (Eds. Comparative Quantification of Health Risks. Geneva: World Health Organization, pp. 597-728.

Maranik, E. 2015. Detox Smoothies Lose weight with smoothies and juices. H. F. Ullmann, Potsdam, Germany, pp. 9-141.

Marsh, A.J., Hill, C., Ross, R.P. and Cotter, P.D. 2014. Fermented beverages with health-promoting potential: past and future perspectives. Trends Food Sci. Technol., 38: 113-24.

McCarron, D.A. 1998. Diet and Blood Pressure- The paradigm shift. Science, 281(5379): 933-934.

McCartney, D., Langston, K., Desbrow, B., Khalesi, S. and Irwin, C. 2019. The influence of a fruit smoothie or cereal and milk breakfast on subsequent dietary intake: a pilot study. International Journal of food sciences and nutrition, 70(5): 1-11.

McCartney, D., Rattray, M., Desbrow, B., Khalesi, S. and Irwin, C. 2018. Smoothies: Exploring attitudes, beliefs, and behaviours of consumers and non-consumers. Current research in nutrition and food science, 6(2): 425-436.

McGhie, T.K., Hunt, M. and Barnett, L.E. 2005. Cultivar and growing region determine the antioxidant polyphenolic concentration and composition of apples grown in New Zealand. Journal of Agricultural and Food Chemistry, 53: 3065-3070.

McIntosh, G.H., Royle, P.J., LeLeu, R.K., Regester, G.O., Johnson, M.A., Grinsted, R.L., Kenward R.S. and Smithers, G.W. 1998. Whey proteins as functional food ingredients? International Dairy Journal, 8(5-6): 425-434.

Meyer, R.S., Cooper, K.L., Knorr, D. and Lelieveld, H.L.M. 2000. High-pressure sterilization of foods. Food Technol., 54(11): 67-72.

Miller, G.D., Jarvis, J.K. and McBean, L.D. 1995. Handbook of Dairy Foods and Nutrition, CRC Press, Boca Raton, Ann Arbor, London, Tokyo.

Mintel Group. Smoothies - Market Intelligence Report; London, U.K., Oct 2008

Mobarhan, S. 2009. Calcium and the colon: Recent Findings. Nutrition Reviews, 57(4): 124-126.

Mordor Intelligence. 2017. Global smoothies market- major trends, growth and opportunities. (2017-2022).

Mytton, O.T., Nnoaham, K., Eyles, H., Scarborough, P. and NiMhurchu, C. 2014. Systematic review and meta-analysis of the effect of increased vegetable and fruit consumption on body weight and energy intake. BMC Public Health, 14: 886.

Oey, I., Van der Plancken, I., Van Loey, A. and Hendrickx, M. 2008. Does high pressure processing influence nutritional aspects of plant based food systems? Trends Food Sci. Technol, 19(6): 300-308.
Okoko, B.J., Burney, P.G., Newson, R.B., Potts, J.F. and Shaheen, S.O. 2007. Childhood asthma and fruit consumption. European Respiratory Journal, 29: 1161-1168.

Olivo, L. 2015. Taking the active nutrition market to new heights. Nutraceuticals World, 18(8): 52-64.

Ouwehand, A.C., Kirjavainen, P.V., Shortt, C. and Salminen, S. 1999. Probiotics: mechanisms and established effects. International dairy journal, 9(1): 43-52.

Park, Y.S., Ham, K.S., Park, Y.K., Leontowicz, M., Namiesnik, J., Katrich, E. and Gorinstein, S. 2016. The effects of treatment on quality parameters of smoothie-type 'Hayward' kiwi fruit beverages. Food Control, 70: 221-228.

Patras, A., Brunton, N.P., Da Pieve, S. and Butler, F. 2009 Impact of high pressure processing on total antioxidant activity, phenolic, ascorbic acid, anthocyanin content and colour of strawberry and blackberry purees. Innovative Food Sci. Emerging Technol., 10(3): 308-313.

Ramachandran, P. and Nagarajan, S. 2014. Quality characteristics, nutraceutical profile and storage stability of aloe-gel papaya functional beverage blend. International Journal of Food Science, 6: 1-7.

Rani, R., Kumar, M.H.S. and Sabikhi, L. 2016. Process optimization for a ready-to-serve breakfast smoothie from a composite milk-sorghum base. International Journal of Dairy Technology, 69(3): 372-379.

Rodriguez-Verastegui, L.L., Martinez-Hernandez, G.B., Castillejo, N., Gomez, P.A., Artes, F. and Artes-Hernandez, F. 2015. Bioactive compounds and enzymatic activity of red vegetable smoothies during storage. Food and Bioprocess Technology, 9(1): 137-146.

Roethenbaugh, G. 2005. Ingredients. In Chemistry and Technology of soft drinks and fruit juices. Ashurst, P.R. (Eds.), Sheffield Academic Press, England, pp. 15-34.

Sabbe, S., Verbeke, W. and Damme, P.V. 2009. Analysing the market environment for acai (Euterpe oleracea Mart.) juices in Europe. Fruits, 64(5): 273-284.

Saranyambiga, D., Narayanan, R. and Vadivoo, V.S. 2017. Development of Jamun symbiotic smoothie. International Journal of Science, Environment and Technology, 6(4): 21792189.

Sayed, A. \& Abdellatif, A. 2018. The Beverages. Agri. Res. E Tech: Open Access J., 14(5): 1-9.

Schulze, M.B., Liu, S., Rimm, E.B., Manson, J.A.E., Willett, W.C. and Hu, F.B. 2004. Glycemic index, glycemic load, and dietary fiber intake and incidence of type 2 diabetes in younger and middle-aged women. American Journal of Clinical Nutrition, 80: 348-356.

Slavin, J.L. and Lloyd, B. 2012. Health benefits of fruits and vegetables. American Society for Nutrition, 3: 506-516.

Southgate, D.A.T., Paul, A.A., Dean, A.C. and Christie, A.A. 1978. Free sugars in foods. J. Hum. Nutr., 32: 335-347. 
Steinmetz, K.A. and Potter, J.D. 1996. Vegetable, fruit and cancer epidemiology. Cancer Causes and Control, 2: 325-351.

Stubbs, R.J. and Whybrow, S. 2004. Energy density, diet composition and palatability: influences on overall food energy intake in humans. Physiol. Behav., 81(5): 755-764.

Suhag, N. and Singh, P. 2017. Functional non-alcoholic beverages: shift in the purchasing patterns of non-alcoholic beverages. American International Journal of Research in Humanities, Arts and Social Sciences, 18(1): 41-45.

Sun-Waterhouse, D., Bekkour, K., Wadhwa, S.S. and Waterhouse, G.I. 2013. Rheological and chemical characterization of smoothie beverages containing high concentrations of fibre and polyphenols from apple. Food and Bioprocess Technology, 7(2): 409-423.

Sun-Waterhouse, D., Farr, J., Wibisono, R. and Saleh, Z. 2008a. Fruitbased functional foods: I. Production of novel food grade apple fibre ingredients. International Journal of Food Science and Technology, 43: 2113 -2122.

Sun-Waterhouse, D., Luberriaga, C., Jin, D., Wibisono, R., Wadhwa, S.S. and Waterhouse, G.I.N. 2011. Juices, fibres and skin waste extracts from white, pink or red fleshed apple genotypes as potential food ingredients: a comparative study. Food and Bioprocess Technology, 6(2): 377390.

Sun-Waterhouse, D., Melton, L.D., O'Connor, C.J., Kilmartin, P.A. and Smith, B.G. 2008b. Effect of apple cell walls and their extracts on the activity of dietary antioxidants. Journal of Agricultural and Food Chemistry, 56(1): 289-295.

Teixeira, N.S., Torrezan, R., Freitas-Sa, D.D.G.C., Pontes, S.M., Ribeiro, L.D.O., Cabral, L.M.C. and Matta, V.M.D. 2019. Development of a fruit smoothie with solid albumen of green coconut. Ciencia Rural, 49(1): 1-8.

Tiwari, U. 2018. Chapter-14-Production of fruit-based smoothies fruit juices. San Deigo: Academic Press, pp. 261278.

Troiano, R.P., Briefel, R.R., Carroll, M.D. and Bialostosky, K. 2000. Energy and fat intakes of children and adolescents in the United States: data from the National Health and Nutrition Examination Surveys. Am. J. Clin. Nutr., 72(5): 1343-1353.
Tucker, K.L. 2004. Dietary intake and coronary heart disease: A variety of nutrients and phytochemicals are important. Prevention, 6: 291- 302.

Verbeke, W., Scholderer, J. and Lahteenmaki, L. 2009. Consumer appeal of nutrition and health claims in three existing product concepts. Appetite, 52(3): 684-692.

Walkling-Ribeiro, M., Noci, F., Cronin, D.A., Lyng, J.G. and Morgan, D.J. 2010. Shelf-life and sensory attributes of a fruit smoothie-type beverage processed with moderate heat and pulsed electric fields. LWT-Food Science and Technology, 43(7): 1067-1073.

Weemaes, C., Ludikhuyze, L., Van Den Broeck, I. and Hendrickx, M. 1999. Kinetic study of anti-browning agents and pressure inactivation of avocado polyphenoloxidase. J. Food Sci., 64(5): 823-827.

Whitney, E. and Rolfes, S.R. 2008. Understanding Nutrition. Ohio: Cengage Learning, Print.

Williams, E., Stewart-Knox, B. and Rowland, I. 2004. A qualitative analysis of consumer perceptions of mood, food and mood-enhancing functional foods. Journal of Nutraceuticals, Functional \& Medical Foods, 4(3/4): 61-83.

Wootton-Beard, P.C. and Ryan, L. 2011. Improving public health: the role of antioxidant-rich fruit and vegetable beverages. Food Res Int, 44(3): 135-148.

Zhang, X., Shu, X., Xiang, Y., Yang, G., Li, H., Gao, J., Cai, H., Gao, Y. and Zheng, W. 2011. Cruciferous vegetable consumption is associated with a reduced risk of total and cardiovascular disease mortality. American Journal of Clinical Nutrition, 94: 240-246.

Zlabur, J. S., Dobricevic, N., Pliestic, S., Galic, A., Bilic, D. P. and Voca, S. 2017. Antioxidant Potential of fruit juice with added Chokeberry powder (Aronia melanocarpa). Molecules, 22(12): 2158.

Zohouri, F.V., Rugg-Gunn, A.J., Fletcher, E.S., Hackett, A.F. and Moynihan, P.J. 2004. Changes in water intake of Northumbian adolescents 1980 to 2000. British Dental Journal, 196(9): 547-552. 